\title{
Assessment of current conditions of the Bílina River in the Czech Republic
}

\author{
M. Neruda ${ }^{1}$, D. Kramer ${ }^{2}$ \& I. Tikhonova ${ }^{2}$ \\ ${ }^{I}$ Faculty of Environment, University of J. E. Purkyně in Ústí nad Labem, \\ Czech Republic \\ ${ }^{2}$ Faculty of Biotechnology and Industrial Ecology, \\ Mendeleev University of Chemical Technology of Russia, \\ Russian Federation
}

\begin{abstract}
River Bílina is a river that flows in the northwestern part of the Czech Republic. From the middle of the $20^{\text {th }}$ century it was used as a water source for several chemical and power plants and thus was greatly affected. The lignite surface mining and mine openings made covering the river with a tube and changing its direction inevitable (with straightening and fortifying as well). In this article we have studied the hydrology, hydrochemistry and bottom sediments of the Bílina River and evaluated its current condition through data obtained.
\end{abstract}

Keywords: Bílina River, field observations, bottom sediments, danger index, possibilities for revitalization.

\section{Introduction}

River Bílina is situated in the northwestern part of the Czech Republic; it is a right tributary of the River Labe (Elbe). Its origin is located near Zákoutí village in the Ore Mountains. Mostly, the river flows in an open bed but part of the river, between the cities Jirkov and Most, is enclosed by a tube. The general direction of the river is southeastern and it has no major tributaries.

The total length of the river is $81 \mathrm{~km}$; the total length in urban areas is about $12 \mathrm{~km}$. The catchment area is $1000 \mathrm{~km}^{2}$ and the mean water flow is $5,90 \mathrm{~m}^{3} \cdot \mathrm{s}^{-1}$. The river flows through such cities as Jirkov, Most, Bílina and Ústí nad Labem where it flows into the River Labe. 
From the middle of the $20^{\text {th }}$ century the River Bílina was used as a water source for several plants such as the Chemopetrol chemical plant, Spolchemie chemical plant, the power plant in Chotějovice and heating station in Trmice. It also served as an outflow for wastewaters from these plants. Nowadays though, these plants either no longer use the Bílina River as a water source or have their own water treatment stations. In most urban parts of the Bílina River its banks are filled with stones and sometimes have very steep slopes. The bottom of the river is also stony and that increases its flow velocity, thus increasing possible erosion and affecting the natural exchange processes between the water and bottom sediments which are almost inaccessible for sampling operations. In some places, for example in Bílina Town, the Bílina River has already been partially revitalized but there are still some places where its riverbed and banks are significantly degraded.

In this work we observed the current condition of the Bílina River and possibilities for its revitalization.

\section{Literature review}

To know and understand the possible ways and methods of river revitalization and its consequences we studied several of the best examples of river revitalization projects in the Czech Republic, Germany, Great Britain and also in South Korea. Here are several of the examples we liked the most.

\subsection{Project for the revitalization of the River Panke in Berlin}

What it is planned to do:

1. The 14 mostly unconquerable barriers (weirs and dams) will be substituted by rough stone ramps or extension of the river course.

2. Everywhere, where possible, trees and bushes will be planted in order to stabilize the river course and prevent erosion. Also, shading of the river would be implemented, therefore preventing an excessive temperature rise in the summer so the content of oxygen would remain at a high level.

3. Several shallow zones will be created for developing sandbanks for mussels, reed belts for dragonflies, rest areas for juvenile fish, etc. Where possible, widening of the river will be realized.

The main goal of the project is to restore the natural riverbed with sandbanks and small islands for vegetation, stone rocks and dead trees for developing the diversity of the river course. These elements must be put into the river properly and safely for the improvement of flood protection. Regular maintenance is also required [1].

\subsection{Project for the revitalization of the River Morava in Olomouc}

Aims of the project:

1. Creation and improvement of habitats for fish and crustaceans, increasing biodiversity of river habitants.

2. Improvement of flood protection. 
3. Arrangement of a recreational area in the alluvial zone of the river with cycle and pedestrian paths, swimming areas and children's playgrounds.

4. Arrangement of a green zone and park in the area of the river flow.

During the implementation of the project the following activities will take place: bifurcation of the actual riverbed and modelling a low central holm, presence of the convex gravel deposits, alternating pond and ford sections, using river wood for embankment, dividing a right side bank ledge into two elevation steps, a suitable plant of bank vegetation, a new approach to the river for town inhabitants, construction of a new path and the dam crest will be strengthened and used as a cycle path. Total costs of the project are estimated at about 350 million Czech crones with 30 million to be spent on river restoration [3].

\subsection{Revitalization of the River Skerne in Hauphton-la-Skerne and Darlington}

Aims of the project:

1. Restoration of $2 \mathrm{~km}$ of the river in terms of physical features, flood management, habitat diversity, water quality, landscape and access to the community.

2. Application of innovative restoration techniques and best management practice within the urban territory.

3. Development of a complex monitoring system to gain further knowledge and understanding of the revitalization process and practical demonstration of the results to the local community and wider audience.

During the project implementation the riverbed was meandered where it was possible, a new channel was created and the old one was filled in. The riverbanks were reprofiled to reach more natural conditions. The flood plain land was lowered to store water at times of high flows. The sewerage system and outfall system were improved and shallow wetland on the lowered floodplain was created. New habitats were created, along with several new paths along the river banks, new bridges and areas of public access to the river. The site of river's flow was vegetated with the help of the local community [4].

\subsection{Revitalization of the River Cheonggyecheon in Seoul}

The implementation of the revitalization project was carried out in 2005. The main goal of the project was not to restore the original image of the river but to create an open area in a landscape dominated by skyscrapers and to create a wildlife corridor alongside with a park and exhibition areas. In addition to removing the expressway and concrete cover, the design incorporated new roads, a sewerage and storm water pipe network and had to allow for flooding. The water for the river is pumped from the nearby Ham River via a water treatment plant. This supplies enough water to maintain an average stream depth of $40 \mathrm{~cm}$. The riverbed contains many artificial weirs and fountains, ensuring that the water oxygen content stays high. Further downstream there is a good enough water quality for invertebrates and fish to establish permanent populations. A survey 
on the ecology of the stream conducted in 2007 found 30 species of birds and 13 species of fish inhabiting the stream environment [6].

We used these projects as a basis for possible revitalization implementations for Bílina River. Our thoughts and suggestions for revitalization can be found in Section 5 .

\section{Methodology and field observations}

\subsection{Field observations}

The first part of our work was to observe the visual condition of the Bílina River by photographing the area. Our goal was to make a description of the coast and vegetation and to identify possible sources of pollutants in the river.

Field observations were carried out in three cities: Ústí nad Labem, Most and Bílina.

\subsection{Sampling operations}

On the basis of the results of our field observation of Bílina River we chose nine profiles (sampling points). In each profile, four samples were taken: two samples of water (one in a plastic bottle for analysis of heavy metal concentrations, the second for NES in a glass bottle) and two samples of bottom sediments. For the sampling of bottom sediments we used small plastic pockets, with the help of a plastic shovel. Table 1 shows the location of the profiles. In some of them we also measured water temperature.

Table 1: $\quad$ Location of profiles and water temperature (where measured).

\begin{tabular}{|c|l|c|}
\hline Profile № & \multicolumn{1}{|c|}{ Location } & Water t $\left({ }^{\circ} \mathrm{C}\right)$ \\
\hline 9 & Most, near Most lake & 12,6 \\
\hline 8 & Most, near train station & 12,6 \\
\hline 7 & Bílina, near «Interspar» & 12,2 \\
\hline 6 & Chotějovice, near power plant & \\
\hline 5 & Trmice, Vaclav square (no access to river) & \\
\hline 4 & Trmice, hydrological station & 12,5 \\
\hline 3 & Trmice, Ždírnický potok stream & 12,6 \\
\hline 2 & Ústí nad Labem, west train station & \\
\hline 1 & Ústí nad Labem, flow into Labe & \\
\hline
\end{tabular}

We were not able to take samples from our fifth profile as there was no access to the river at that point. The sampling operation took place on 27.04.2011.

\subsection{Analyzing procedures}

In our study we analyzed the concentration of heavy metals and bottom sediments in different parts of the Bílina River. NES samples were analyzed with the help of an infra-red spectrometer. The first couple of heavy metals samples 
were analyzed on ICP in order to know the concentration of all heavy metals in samples. Then we chose several heavy metals with the highest concentrations and measured them with an atomic absorption spectrometer.

Sample preparation procedures were as follows:

1. For NES.

2. Analyses for NES were undertaken according to Czech national regulation ČSN 757505 (water), ČSN 757505 and ČSN 757506 (sediment).

3. For heavy metals.

$2 \mathrm{~g}$ of sediment is weighed and mixed with $7 \mathrm{ml}$ of nitric acid, this mixture stand overnight. To this mixture $21 \mathrm{ml}$ of hydrochloric acid is added and the obtained mixture rests for approximately 30 minutes. After 30 minutes the mixture is boiled for two hours on a hot plate. Than the digest is filtered into a $100 \mathrm{ml}$ volumetric flask. The volumetric flask is filled with distilled water and the sample is then ready for ICP-OES analysis.

\section{Results}

\subsection{Hydrological results}

Hydrological measurements were implemented on 12.05.2011 at the fourth profile "Trmice hydrological station". We measured such hydrological parameters as mean velocity, mean discharge, width, depth and water flow area. The measurements were taken with the help of the device ADCP with cooperation of the Czech Hydrometeorological Institute in Ústí nad Labem. The results are in table 2 .

Table 2: Hydrological parameters of the Bílina River at the fourth profile "Trmice hydrological station."

\begin{tabular}{|l|r|}
\hline \multicolumn{1}{|c|}{ Parameter } & Value \\
\hline Mean velocity, m/s & 0,574 \\
\hline Width, $\mathrm{m}$ & 14,27 \\
\hline Depth, $\mathrm{m}$ & 0,743 \\
\hline Water flow area (trapezoidal profile), $\mathrm{m}^{2}$ & 10,6 \\
\hline Mean discharge, $\mathrm{m}^{3} / \mathrm{s}$ & 6,046 \\
\hline
\end{tabular}

\subsection{Legislation}

To determine water and bottom sediments quality we used several Russian and Czech legislative documents for water and bottom sediments. These documents include so called limit allowable concentrations (LAC) [5-10].

The NES LAC for water used for common use $\left(\mathrm{LAC}_{\mathrm{w}}\right)$ is $0,3 \mathrm{mg} / \mathrm{l}$ (normative is for oil), LAC for water used for fisheries $\left(\mathrm{LAC}_{\mathrm{wf}}\right)$ is $0,05 \mathrm{mg} / \mathrm{l}$. To assess contamination of bottom sediments by NES we used a concentration that is considered acceptable for the Moscow region $-1000 \mathrm{mg} / \mathrm{kg}$ (all values given are from Russian legislative documents).

The LAC for heavy metals in different environments is shown in table 3. 
Table 3: The LAC of heavy metals in different environments (including the $\mathrm{LAC}$ for water and bottom sediments in Czech Republic $\left(\mathrm{LAC}_{\mathrm{bs}}\right)$ ).

\begin{tabular}{|l|c|c|c|c|c|c|c|c|}
\hline Norm/substance & $\mathrm{As}$ & $\mathrm{Cd}$ & $\mathrm{Cu}$ & $\mathrm{Ni}$ & $\mathrm{Pb}$ & $\mathrm{V}$ & $\mathrm{Zn}$ & $\mathrm{Hg}$ \\
\hline $\mathrm{LAC}_{\mathrm{w}}(\mathrm{Rus}, \mathrm{mg} / \mathrm{l})$ & 0,01 & 0,001 & 1 & 0,02 & 0,01 & 0,1 & 1 & 0,0005 \\
\hline $\mathrm{LAC}_{\mathrm{wf}}(\mathrm{Rus}, \mathrm{mg} / \mathrm{l})$ & 0,05 & 0,005 & 0,001 & 0,01 & 0,006 & 0,001 & 0,01 & 0,0001 \\
\hline $\mathrm{LAC}_{\mathrm{w}}(\mathrm{CZ}, \mathrm{mg} / \mathrm{l})$ & 0,02 & 0,0007 & 0,025 & 0,04 & 0,0144 & 0,035 & 0,16 & 0,0001 \\
\hline $\mathrm{LAC}_{\mathrm{s}}(\mathrm{Rus}, \mathrm{mg} / \mathrm{kg})$ & 10 & 2,0 & 132 & 80 & 130 & 150 & 220 & 2,1 \\
\hline $\mathrm{LAC}_{\mathrm{bs}}(\mathrm{CZ}, \mathrm{mg} / \mathrm{kg})$ & 30 & 2,5 & 100 & 80 & 100 & 180 & 600 & 0,8 \\
\hline
\end{tabular}

\subsection{Results for NES}

Concentrations of NES in samples are represented in table 4 and changes of NES concentration in bottom sediments in the Bílina River are represented in figure 1.

Table 4: $\quad$ Concentration of NES in samples.

\begin{tabular}{|c|c|c|}
\hline № of profile & NES in water $(\mathrm{mg} / \mathrm{l})$ & NES in bottom sediments $(\mathrm{mg} / \mathrm{kg})$ \\
\hline 1 & $<0,1$ & 423 \\
\hline 2 & $<0,1$ & 112 \\
\hline 3 & $<0,1$ & $\mathbf{1 0 1 0}$ \\
\hline 4 & $<0,1$ & 114 \\
\hline 6 & $<0,1$ & 241 \\
\hline 7 & $<0,1$ & 48 \\
\hline 8 & $<0,1$ & 209 \\
\hline 9 & $<0,1$ & 28 \\
\hline
\end{tabular}

Note: concentration that exceeds Russian LAC for soils is bold.

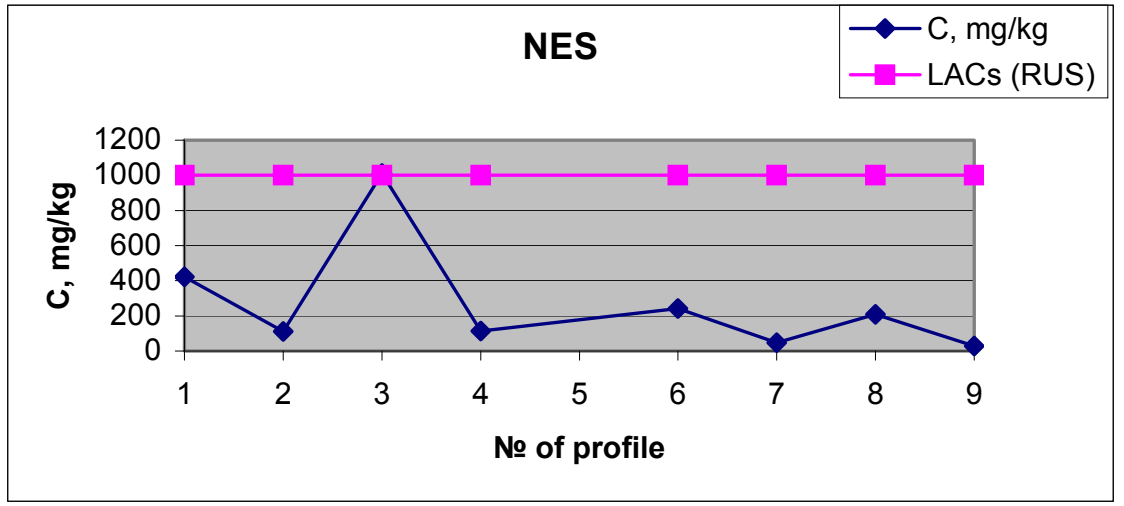

Figure 1: Changes of NES concentration in bottom sediments in the Bílina River. 


\subsection{Results for heavy metals}

\subsubsection{Concentrations of heavy metals in water}

Concentrations of heavy metals in water are represented in table 5.

Table 5: $\quad$ Concentrations of heavy metals in water $(\mathrm{mg} / \mathrm{l})$.

\begin{tabular}{|c|c|c|c|c|c|c|c|c|}
\hline $\begin{array}{c}\text { Substance/№ } \\
\text { of profile }\end{array}$ & 1 & 2 & 3 & 4 & 6 & 7 & 8 & 9 \\
\hline $\mathrm{As}$ & $<0,2$ & $<0,2$ & $<0,2$ & $<0,2$ & $<0,2$ & $<0,2$ & $<0,2$ & $<0,2$ \\
\hline $\mathrm{Cd}$ & $<0,01$ & $<0,01$ & $<0,01$ & $<0,01$ & $<0,01$ & $<0,01$ & $<0,01$ & $<0,01$ \\
\hline $\mathrm{Cu}$ & $<0,02$ & 0,02 & $<0,02$ & $<0,02$ & $<0,02$ & $<0,02$ & $<0,02$ & $<0,02$ \\
\hline $\mathrm{Ni}$ & $<0,02$ & $<0,02$ & $<0,02$ & $<0,02$ & $<0,02$ & $<0,02$ & $<0,02$ & $<0,02$ \\
\hline $\mathrm{Pb}$ & $<0,1$ & $<0,1$ & $<0,1$ & $<0,1$ & $<0,1$ & $<0,1$ & $<0,1$ & $<0,1$ \\
\hline $\mathrm{V}$ & $<0,02$ & $<0,02$ & $<0,02$ & $<0,02$ & 0,02 & 0,03 & 0,03 & 0,03 \\
\hline $\mathrm{Zn}$ & $<0,005$ & $<0,005$ & $<0,005$ & $<0,005$ & $<0,005$ & $<0,005$ & $<0,005$ & $<0,005$ \\
\hline $\mathrm{Hg}$ & $<0,001$ & $<0,001$ & $<0,001$ & $<0,001$ & $<0,001$ & $<0,001$ & $<0,001$ & $<0,001$ \\
\hline
\end{tabular}

\subsubsection{Concentrations of heavy metals in bottom sediments}

Concentrations of heavy metals in bottom sediments are represented in table 6 . Changes of $\mathrm{As}, \mathrm{Zn}$ and $\mathrm{Hg}$ concentrations in bottom sediments in the Bílina River are represented in figure 2 .

Table 6: $\quad$ Analysis of bottom sediments for heavy metals ( $\mathrm{mg} / \mathrm{kg})$.

\begin{tabular}{|c|c|c|c|c|c|c|c|c|}
\hline Substance/№ of profile & 1 & 2 & 3 & 4 & 6 & 7 & 8 & 9 \\
\hline $\mathrm{As}$ & $\mathbf{2 3}$ & $\mathbf{2 0}$ & $\mathbf{3 0}$ & 10 & $\mathbf{1 5}$ & 10 & $\mathbf{2 0}$ & $\mathbf{1 5}$ \\
\hline $\mathrm{Cd}$ & 0,8 & 1,2 & 0,5 & $<0,5$ & 1,0 & 0,5 & 1,5 & 0,5 \\
\hline $\mathrm{Cu}$ & 41 & 32 & 73 & 17 & 38 & 21 & 70 & 18 \\
\hline $\mathrm{Ni}$ & 42 & 43 & 41 & 31 & 41 & 26 & 38 & 22 \\
\hline $\mathrm{Pb}$ & 40 & 47 & 61 & 22 & 35 & 12 & 32 & 25 \\
\hline $\mathrm{V}$ & 100 & 97 & 120 & 61 & 102 & 67 & 119 & 43 \\
\hline $\mathrm{Zn}$ & $\mathbf{2 3 8}$ & 215 & 133 & 129 & 170 & 86 & 144 & 73 \\
\hline $\mathrm{Hg}$ & 0,6 & $\underline{2}$ & 0,7 & 0,1 & 0,2 & 0,2 & 0,6 & 0,1 \\
\hline
\end{tabular}

Note: concentrations that exceed Russian $\mathrm{LAC}_{\mathrm{s}}$ are bold; concentrations that exceed $\mathrm{CZ} \mathrm{LAC}_{\mathrm{bs}}$ are italic and underlined. If the concentration is bold and italic underlined then it exceeds both norms. 

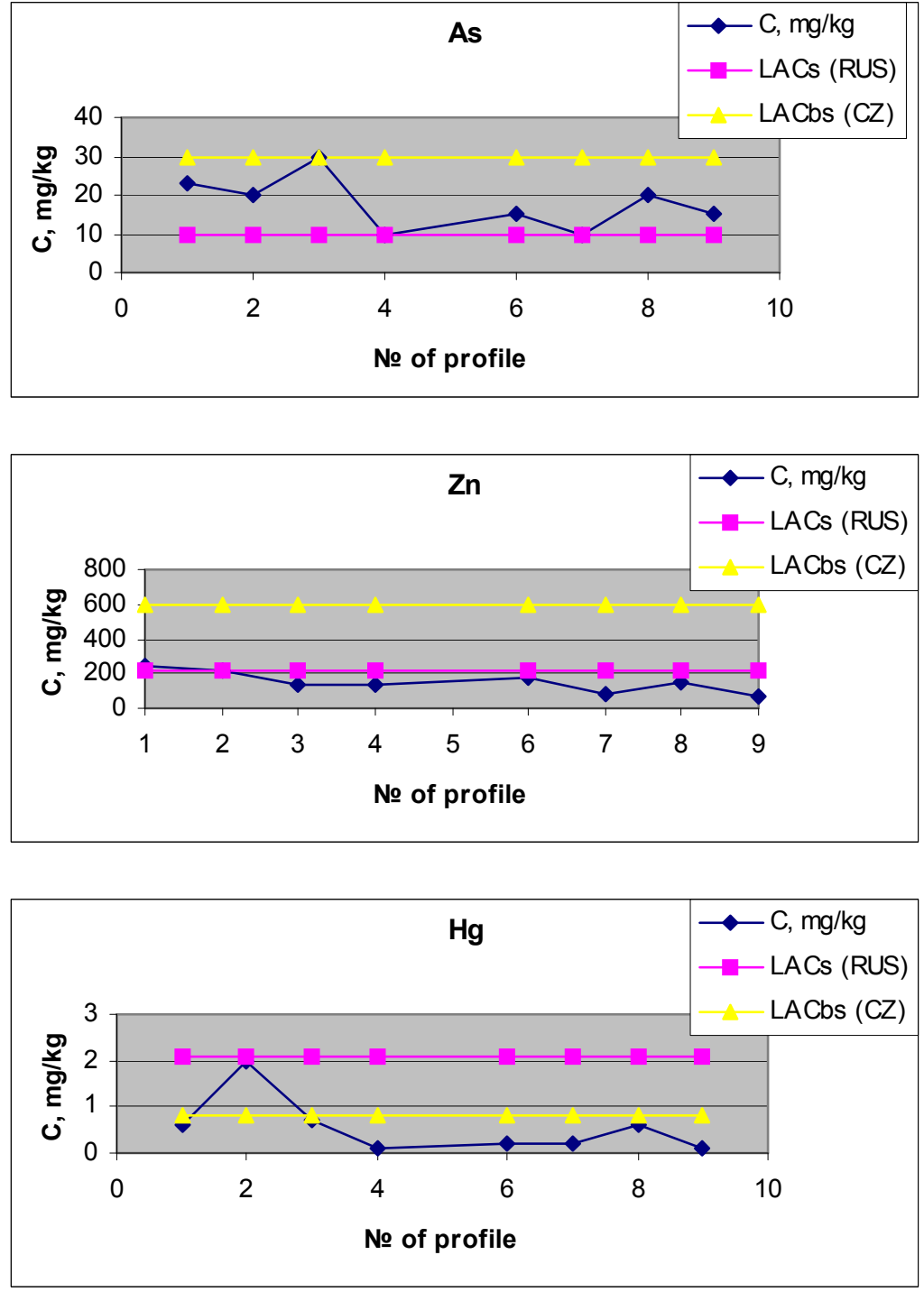

Figure 2: $\quad$ Changes of $\mathrm{As}, \mathrm{Zn}$ and $\mathrm{Hg}$ concentrations in bottom sediments in the Bílina River.

To evaluate pollution of bottom sediments we will use the so-called danger index $\left(\mathrm{I}_{\mathrm{d}}\right)$, which is calculated as follows: $\mathrm{I}_{\mathrm{d}}=\mathrm{C}_{\mathrm{i}} / \mathrm{LAC}_{\mathrm{i}}$. Tables7 and 8 represent danger indexes for heavy metals in bottom sediments with the use of Russian LAC for soils and Czech LAC for bottom sediments respectively. In these tables the sum of these indexes for each profile is also shown (end of column) and each substance (end of line). 
Table 7: Danger indexes for heavy metals in bottom sediments (Russian $\mathrm{LAC}_{\mathrm{s}}$ ).

\begin{tabular}{|c|c|c|c|c|c|c|c|c|c|}
\hline $\begin{array}{c}\text { Substance/ } \\
\text { № of profile }\end{array}$ & 1 & 2 & 3 & 4 & 6 & 7 & 8 & 9 & Sum \\
\hline $\mathrm{As}$ & 2,30 & 2,00 & 3,00 & 1,00 & 1,50 & 1,00 & 2,00 & 1,50 & 14,30 \\
\hline $\mathrm{Cd}$ & 0,40 & 0,60 & 0,25 & 0,00 & 0,50 & 0,25 & 0,75 & 0,25 & 3,00 \\
\hline $\mathrm{Cu}$ & 0,31 & 0,24 & 0,55 & 0,13 & 0,29 & 0,16 & 0,53 & 0,14 & 2,35 \\
\hline $\mathrm{Ni}$ & 0,53 & 0,54 & 0,51 & 0,39 & 0,51 & 0,33 & 0,48 & 0,28 & 3,55 \\
\hline $\mathrm{Pb}$ & 0,31 & 0,36 & 0,47 & 0,17 & 0,27 & 0,09 & 0,25 & 0,19 & 2,11 \\
\hline $\mathrm{V}$ & 0,67 & 0,65 & 0,80 & 0,41 & 0,68 & 0,45 & 0,79 & 0,29 & 4,73 \\
\hline $\mathrm{Zn}$ & 1,08 & 0,98 & 0,60 & 0,59 & 0,77 & 0,39 & 0,65 & 0,33 & 5,40 \\
\hline $\mathrm{Hg}$ & 0,29 & 0,95 & 0,33 & 0,05 & 0,10 & 0,10 & 0,29 & 0,05 & 2,14 \\
\hline $\mathrm{Sum}$ & 5,88 & 6,32 & 6,52 & 2,73 & 4,62 & 2,76 & 5,74 & 3,02 & \\
\hline
\end{tabular}

Table 8: Danger indexes for heavy metals in bottom sediments (Czech $\mathrm{LAC}_{\mathrm{bs}}$ ).

\begin{tabular}{|c|c|c|c|c|c|c|c|c|c|}
\hline $\begin{array}{c}\text { Substance/ } \\
\text { № of profile }\end{array}$ & 1 & 2 & 3 & 4 & 6 & 7 & 8 & 9 & Sum \\
\hline $\mathrm{As}$ & 0,77 & 0,67 & 1,00 & 0,33 & 0,50 & 0,33 & 0,67 & 0,50 & 4,77 \\
\hline $\mathrm{Cd}$ & 0,32 & 0,48 & 0,20 & 0,00 & 0,40 & 0,20 & 0,60 & 0,20 & 2,40 \\
\hline $\mathrm{Cu}$ & 0,41 & 0,32 & 0,73 & 0,17 & 0,38 & 0,21 & 0,70 & 0,18 & 3,10 \\
\hline $\mathrm{Ni}$ & 0,53 & 0,54 & 0,51 & 0,39 & 0,51 & 0,33 & 0,48 & 0,28 & 3,55 \\
\hline $\mathrm{Pb}$ & 0,40 & 0,47 & 0,61 & 0,22 & 0,35 & 0,12 & 0,32 & 0,25 & 2,74 \\
\hline $\mathrm{V}$ & 0,56 & 0,54 & 0,67 & 0,34 & 0,57 & 0,37 & 0,66 & 0,24 & 3,94 \\
\hline $\mathrm{Zn}$ & 0,40 & 0,36 & 0,22 & 0,22 & 0,28 & 0,14 & 0,24 & 0,12 & 1,98 \\
\hline $\mathrm{Hg}$ & 0,75 & 2,50 & 0,88 & 0,13 & 0,25 & 0,25 & 0,75 & 0,13 & 5,63 \\
\hline $\mathrm{Sum}$ & 4,12 & 5,87 & 4,82 & 1,79 & 3,24 & 1,95 & 4,41 & 1,89 & \\
\hline
\end{tabular}

\section{Discussion}

\subsection{Possibilities for revitalization}

For revitalization process we chose part of the Bílina River that flows between the West train station and flow into the Labe River in Usti-nad-Labem. This is the most industrial area of river flow.

Possibilities for revitalization are very limited in this area due to proximities of the motorway from one side and of train station facilities, auto market and other buildings from the other side of the river. Therefore, for example, it is impossible to establish new meanders in the course or to establish any children's 
playgrounds on the riverbanks. Nevertheless, there are several revitalization measurements that can be implemented:

1. Replacement of unfriendly vegetation from riverbanks with lawn grass along with reestablishing the pedestrian pathway. To implement the latter it is necessary to also make reliable stairways because the riverbanks are very steep (and the slopes cannot be changed due to the reasons mentioned above) but there is a natural platform that allows for reestablishing the vegetated pathway.

2. Removal of the stones from the riverbed that will decrease flow velocity and thus decrease possible erosion risk and also will reestablish exchange processes between water and bottom sediments.

3. Establishment of shallow areas close to river banks with vegetation like reed thickets for example. Some dead trees and little stone rocks can be also be put to the riverbed to make some hiding places for fish (thus reestablishing its population) and to give a more natural view to the river.

These implementations will have mostly an ecological impact but could also be beneficial to the local community in terms of fishing.

\subsection{Results from analyzes}

As shown in table 3, concentrations of NES in water do not exceed Russian $\mathrm{LAC}_{\mathrm{w}}$ and concentrations of NES in the bottom sediments exceed Russian LAC only in the third profile with concentrations in other profiles being significantly lower. High concentration of NES in the bottom sediments in third profile can be explained by the impact of the Ždírnický potok stream that flows through the urban part of Ústí nad Labem.

From table 4 it can be seen that the Bílina River contains very slight concentrations of heavy metals in water with most of them being under the measuring limit. There is no concentration that exceeds either Russian $\mathrm{LAC}_{\mathrm{w}}$ or Czech $\mathrm{LAC}_{\mathrm{w}}$. As far as bottom sediments are concerned (table 5), we also say that they are mostly clean but there are several concentrations that exceed Russian $\mathrm{LAC}_{\mathrm{s}}$ and the concentration of $\mathrm{Hg}$ in profile 2 exceeds Czech $\mathrm{LAC}_{\mathrm{bs}}$. Concentration of As is higher than Russian LACs in six out of eight profiles and the possible explanation for this fact is the stability of compounds containing As. A high concentration of $\mathrm{Hg}$ in profile 2 could occur because of the closeness of the train station and its facilities to the profile. A slight excess of $\mathrm{Zn}$ concentration in profile 1 compared to Russian $\mathrm{LAC}_{\mathrm{s}}$ can be explained by building works that occurred there at time of sampling.

Before we evaluate the danger indexes that we calculated it is interesting to compare Russian and Czech legislative norms for heavy metals. As can be seen from table 2, Russian LACw norm is lower than Czech LACw norm for As, Ni and $\mathrm{Pb}$. For other heavy metals analyzed it is vice versa. Also from this table you can see that Russian $\mathrm{LAC}_{\mathrm{s}}$ is lower for As, Cd, V and $\mathrm{Zn}$ with Czech $\mathrm{LAC}_{\mathrm{bs}}$ being lower for $\mathrm{Cu}, \mathrm{Pb}$ and $\mathrm{Hg}$. For $\mathrm{Ni}$ these norms are equal. The biggest differences occur for As and $\mathrm{Zn}$ where Russian LACs is 3 and 2,7 times 
respectively lower than Czech $\mathrm{LAC}_{\mathrm{bs}}$. Czech $\mathrm{LAC}_{\mathrm{bs}}$ for $\mathrm{Hg}$ is 2,6 times lower than Russian norm for this substance.

According to danger indexes using Russian $\mathrm{LAC}_{\mathrm{s}}$ (table 6) the most polluted profiles are profiles 1, 2 and 3 that can be explained by the impact of the Ždírnický potok stream in profile 3 and flowing in an industrial part of Ústí nad Labem for profiles 1 and 2. The most dangerous substances are As, Zn and V; with As being the most dangerous substance by far. The least dangerous are profile 4 and $\mathrm{Pb}$ as a substance. When we used Czech LACbs for calculating danger indexes (table 7) the most polluted profiles were profiles 2, 3 and 8 . Lower danger index of profile 1 can be explained by the difference in legislative norms for $\mathrm{Zn}$. Profile 8 is situated in an urban part of Most Town which explains the relatively high danger index. Most dangerous substances are $\mathrm{Hg}$, As and $\mathrm{V}$. Substitution of $\mathrm{Zn}$ with $\mathrm{Hg}$ is also explained by the difference in legislative norms for these substances. The least dangerous profile is profile 4 and the least dangerous substance is $\mathrm{Zn}$.

After analyzing the results we obtained we came to the conclusion that the Bílina River had a good self-purification process that lasts for approximately 20 years when nearby plants stopped using it as an outflow for wastewaters. That means that self-purification (and thus self-restoration) processes in small rivers are not only possible but can occur quite quickly though the ecosystem of the Bílina River still suffers greatly from anthropogenic impact. The river can greatly benefit from little human assistance in revitalization and can be restored sooner than seems possible.

\section{Conclusion}

In this article we tried to make a complex evaluation of the current condition of the Bílina River starting with field observations and finishing with an assessment of bottom sediments. We studied the Bílina course either in green areas such as part of the river between Bílina Kyselka train station and Interspar shopping center in Bílina Town or in urban industrial areas such as part of the river between West train station in Ústí nad Labem and its flow into the Labe River. We also carried out hydrological and hydrochemical observations along with observations of bottom sediments.

After evaluating the results obtained we can say that Bílina River's water is clean in terms of NES and heavy metal concentration and bottom sediments are only slightly polluted with $\mathrm{As}, \mathrm{Zn}$ and $\mathrm{Hg}$. We consider the Bílina River as a good example of a river self-purifying and we hope that this article will also improve the river's image in the eyes of the community.

\section{References}

[1] M. Neruda, E. Molnár, P.M. Crory, U. Voigt, M. Beyhan, A. Dogan, M. Kitis, Environmental water management, Faculty of Environment UJEP Ústí nad Labem, 2010. 
[2] Reuris - Revitalization of Urban River Spaces. Good practice examples. Brno city, pp. 46-52, 93-94, 2009.

[3] River Skerne Brochure. The River Restoration Center, 1998.

[4] T. Davie, Fundamentals of Hydrology - Routledge fundamentals of physical geography, second ed., Routledge Taylor \& Francis Group, New York, pp. 171-172.

[5] Russian Federation State Committee for Fisheries decree №20 from 18th January 2010 "About fisheries legislations" (name shortened).

[6] Hygienic norms GN 2.1.5.1315-03 "Limit allowable concentrations (LAC) in water for water objects for common uses".

[7] Hygienic norms GN 2.1.7.2041-06 "Limit allowable concentrations (LAC) of substances in soil".

[8] Approximate allowable concentrations (AAC) of substances in soil. Hygienic norms GN 2.1.7.2042-06.

[9] Act N. 185/2001 Coll., about wastes.

[10] Government regulation, N. 61/2003 Coll. about parameters of surface water pollution (name shortened). Novelization: N. 229/2007 Coll. 